\title{
The Impact of Climate Change on Tourism: A Causality Analysis
}

\begin{abstract}
Murat Atasoy,a,", Filiz Guneysu Atasoy ${ }^{2, b}$
${ }^{1}$ Department of Interior Architecture and Environmental Design, Faculty of Architecture, Osmaniye Korkut Ata University, 80010 Osmaniye, Turkey

${ }^{2}$ Department of Economics, Faculty of Economics and Administrative Sciences, Osmaniye Korkut Ata University, 80010 Osmaniye, Turkey *Corresponding author

\begin{tabular}{l|l}
\hline A R T I C L E I N F O & A B S T R A C T \\
\hline $\begin{array}{l}\text { Research Article } \\
\text { Received : 11/12/2019 }\end{array}$ & $\begin{array}{l}\text { Tourism industry is one of the primary sectors that contribute to economic growth of countries } \\
\text { worldwide. Since it requires appropriate weather conditions and clean environment, climate changes } \\
\text { can significantly affect the sector. Therefore, this study examines the causality and long-run } \\
\text { relationship between the climate change and tourism sector in Turkey. To estimate the potential } \\
\text { long-run relationship between variables, Granger-Causality test is applied to data from 1960 to 2016. } \\
\text { The study uses World Development Indicator Data released by World Bank. For the analysis, } \\
\text { carbon-dioxide emission, methane emission, energy use (oil equivalent), and forest land are standing } \\
\text { for climate change indicators. International tourist arrivals and tourism revenues represent for } \\
\text { tourism sector's variables. The findings show that there is a negative and significant coefficient of } \\
\text { climate change on tourism sector. Also, in average, climatic change indicators have unidirectional } \\
\text { and negative impact on international tourism revenue. Another finding is that climate change } \\
\text { deteriorates to environment by augmenting carbon dioxide emission and methane emission. As a } \\
\text { result, climatic change can weaken the tourism industry which can decrease the speed of Turkey's } \\
\text { economic development. In the long run, this research can pioneer assessing the economic and } \\
\text { environmental impacts of climate change in the tourism sector bases. }\end{array}$ \\
$\begin{array}{l}\text { Keywords: } \\
\text { Causality analysis } \\
\text { Climate change } \\
\text { Economic effect } \\
\text { Environmental degradation, } \\
\text { Tourism sector }\end{array}$
\end{tabular}
\end{abstract}

muratatasoy@osmaniye.edu.tr

iD https://orcid.org/0000-0003-0987-521X

|'bfilizatasoy@osmaniye.edu.tr

iD https://orcid.org/0000-0003-1413-9954

(c) (1) (9) This work is licensed under Creative Commons Attribution 4.0 International License

\section{Introduction}

Nowadays, fossil fuels usage and greenhouse gases deteriorate to environment by carbon dioxide, methane nitrous oxide, and ozone etc. emission. This situation inevitably causes climate change. Estimation of environmental degradation lead by climate change is still ambiguous since natural driving factors are uncertain (Collins et. al, 2013). Energy consumption and access to energy usage are universal rights and limitations to access of energy usage due to climate change scenarios by increasing prices can result with social acceptability issue (Jean-Baptiste and Ducroux, 2003). As a result of climate change, energy demand of countries has dramatically increased due to uncomfortable air conditions, humidity in cold seasons, increase in land surface temperature, and irregular precipitation activities (Roshan et al., 2012). For instance, in Hong Kong, energy consumption for air conditioning has increased from $1120 \mathrm{GW}$ h in 1979 to 7646 GW h in 2008 (Lam et al., 2010).

The climate change and density of extreme weather events can determine the amount of energy demand, delivery, and consumption (Akhmat et al., 2014). The electricity use demand is expected to rise due to electrical consumer goods which can lead to increase in greenhouse gas and surface temperature in developing and developed countries (Collins et. al., 2010). For conservation the energy sources and reduce climate risks, many mitigation activities such as fuel-efficient vehicles, renewable energy use, and afforestation activities for carbon sequestration revealed to minimize the global warming (Semenza et al., 2011).

Since the deterioration of climate change can be observed in nature, many sectors are affected from it, such as tourism, labor, agriculture, health sectors and economic growth of countries. First effect of the climate change can be realized as increase in temperature and density of precipitation or drought. Munich (2013) stated that from 1980 to $2012,87 \%$ of the natural disasters occurred due to climate-related natural disasters. The rate of the natural disasters is $44 \%, 41 \%$ and $15 \%$ caused by storms, floods and drought in sequences. The aforementioned natural diseases lead to 2.8 trillion economic losses (Munich, 2013). It is estimated that these economic losses caused by climate change will be around 1 trillion dollars annually in the 2050s 
(Hallegatte et al., 2013). Climate is the main element in the development of agricultural output. Therefore, changes in temperature, precipitation and amount of $\mathrm{CO}_{2}$ emission in the atmosphere can negatively affect the agricultural sector (Dellal, 2008). In addition, tourism sector can be affected from climate changes, since tourism requires a clean environment and favorable weather conditions for tourist satisfaction (United Nations World Tourism Organization, and here after-UNWTO, 2007).

Moreover, economic growth is affected by climatic differences. Since the indicator of economic growth of countries is GDP, and GDP is compiled of the amount and efficiency of output which can be stated in a production function (Y). A production function relates the input of factors of production to the output of goods. The production includes a function of labor, physical capitals, natural and land resources. The amount of production and its' productivity can be influenced by unexpected severe and frequent weather changes. Therefore, the changes can alter the level and trend of production (Nakicenovic, 2010).

Saanz de Miera and Rossello (2014) stated the three S (3S) of the tourism: sea, sand, and sun, which are degenerated by climate change. Tourism industry has sharp impact on countries' economic development and this sector has been impacted by the climate change due to increased demand for energy usage (Katircioglu, 2014). According to Sajjad et al. (2014), tourism pioneers $5 \%$ of the world GDP and international tourism is the world's fourth largest global export leader with an industrial return of $\$ 1$ trillion annually, representing $30 \%$ of world's commercial service products. For instance, in the Southeast Asia, tourism plays a vital role for the income of region's many countries in the aspects of travel, accommodation, business, and restaurants which therefore lead to havoc environmental consequences such as air pollution and natural resource contamination (Climate and Development Knowledge Network-CDKN, 2013).

There have been several studies focused on the relationship between tourism and climate. Lohmann and
Kaim (1999) conducted surveys with tourists to investigate how important the destination characteristics such as landscape and weather were in the tourism sector. The researchers reported that further research examining the effects of weather on destination choice decisions was required to increase the tourism revenue in Germany. Cunliffee (2002) used the Delphi method to evaluate the qualitative techniques for forecasting economic development of tourism industry in relation to climate change in tropical coastal areas and found that forecasting environmental hazards can increase the economic return derived from coastal tourism aspects. Katircioglu et. al. (2014) investigated the relationship among international tourism, energy consumption and $\mathrm{CO}_{2}$ emission of Cyprus. The authors used unit root tests, bound tests and granger causality test. Their study results showed that international tourism is incentive for a rise of carbon dioxide emission of Cyprus. Therefore, understanding the relationship between environmental degradations caused by climate change and their impacts on tourism sector can be an important factor to explain tourism revenues.

Some climate change and tourism indicators are represented in Table 1 for a better understanding of changes. The data show that the $\mathrm{CO}_{2}$ emission, and methane emission has been increased more than twice last forty years. Additionally, energy usage has been escalated from 1960 to 2014, which is most recent available data set. Therefore, it is important to reveal the potential impact of climate change and tourism indicators.

As stated in the current study, climatic changes have many impacts on sectors, however; the literature is limited in terms of tourism sector and climate change relationship in Turkey. Thus, the purpose of this study is to analyze the impact of climate change on the Turkish Tourism Sector. For this aim, this study uses $\mathrm{CO}_{2}$ emission, methane emission, international tourist arrivals, international tourism revenue, forest depletion and gross domestic products per capita as fundamental data sets from 1960 to 2016.

Table 1. Climate change and tourism indicators from 1960 to 2016

\begin{tabular}{c|lccccc}
\hline Years & ITA & EK & ME & EU & AL & FA \\
\hline 1960 & 124.2 & - & - & 389.114 & 47.447 & - \\
1970 & 724.8 & - & $32,789.2$ & 511.562 & 49.606 & - \\
1980 & 1057.4 & - & $39,597.1$ & 776.765 & 50.127 & - \\
1990 & 5397.7 & $150,667.3$ & $43,852.1$ & 977.663 & 51.553 & 12.502 \\
1995 & 7747.4 & $176,560.8$ & $48,599.9$ & $1,052.698$ & 51.314 & 12.867 \\
2000 & $10,428.2$ & $215,970.8$ & $56,261.3$ & $1,201.086$ & 52.595 & 13.231 \\
2005 & $21,124.9$ & $237,174.4$ & $64,354.9$ & $1,240.165$ & 53.562 & 13.853 \\
2010 & $31,396.1$ & $298,002.3$ & $77,306.8$ & $1,474.668$ & 50.689 & 14.556 \\
2014 & $39,811.0$ & $345,981.45$ & $78,852.9 *$ & $1,573.716$ & 50.103 & 15.089 \\
2016 & $30,289.0$ & - & & - & 49.799 & 15.335 \\
\hline
\end{tabular}

ITA: International Tourist Arrivals (thousands); EK: $\mathrm{CO}_{2}$ Emission in kt; ME: Methane Emission (kt of $\mathrm{CO}_{2}$ ); EU: Energy Use (kg of oil equivalent per capita); AL: Agricultural Land (\%); FA: Forest Area (\% of land area); International Tourism Arrivals are obtained from TURKSTAT. $\mathrm{CO}_{2}$ emission, energy usage, agricultural land and forest area data are retrieved from World Development Indicator data set. $\mathrm{CO}_{2}$ emission data available from 1990 to 2014 and forest land area is available from 1990 to 2016. Methane emission is available until 2012.

\section{Material and methods}

For the present study, the data set are annual figures covering years from 1960 to 2016. The data set are restricted with 2016 which was the most recent available year for data in terms of forest land in Turkey. First, the variables of the study are international tourist arrivals representing Turkey's tourism establishment, international tourism revenue per year and named as TOU. Other variables are $\mathrm{CO}_{2}$ emission in $\mathrm{kt}$, energy usage $(\mathrm{kg}$ of oil equivalent), Methane emission ( $\mathrm{Kt}$ of $\mathrm{CO}_{2}$ ) and forest land (\% of the area) representing for climate change (CC). Some 
studies use $\mathrm{CO}_{2}$ emission as an indicator of Greenhouse gas emission, but the current study directly uses as $\mathrm{CO}_{2}$ emission because there is more than one type of gases, such as $\mathrm{CO}_{2}$, methane, nitrous oxide, ozone, chlorofluorocarbon etc., but not all data are available. Therefore, the study uses $\mathrm{CO}_{2}$ emission and methane emission terms separately instead of using greenhouse gas emission. As explanatory variable of the study, the gross domestic product (GDP) per capita is applied.

Tourism and GDP variables are retrieved from Turkish Statistics Institute (here after is TURKSTAT). The data set of $\mathrm{CO}_{2}$ emission $\left(\mathrm{CO}_{2}\right)$, methane emission (MET) energy usage (EN) and Forest Land (FL) are obtained from the World Development Indicator which is released by the World Bank. The data set are available online at the World Bank and TURKSTAT.

First, all data set are compile of yearly data; therefore, it may exhibit nonstationary characteristics. To eliminate the problem, the Augmented Dickey-Fuller (ADF) technique is applied. Then, a suitable lag is selected for the analysis. Then, all of variables in the study are nondifferenced data set which is calculated by vector autoregression method. It is used Akaike Information
Criteria to minimize and Johansen-Juselius (1990) cointegration test is applied for determination the potential long term relationship.

Tourism and Climate change variables functional relationship given in equation 1 ;

Where TOU represents the tourism indicator and CC is standing for climate factors, i.e. $\mathrm{CO} 2$ emission, energy usage, and forest land. All $\beta$ are coefficient estimated in the equation, and $\mathrm{t}$ is a time variable of the year. $\Delta$ is a difference operator and $\varepsilon$ is a error term. After that, Granger Causality test is applied to estimation of the potential direction among variables (Equation 2 and 3).

Where the equation $\ln$ is natural logarithm and $\Delta$ represents the first difference of the variables. $\epsilon_{t}$ is the normally distributed white noise, and $\epsilon_{t-1}$ is one period lag of error term.

After that both short term and long term causality relationship are estimated. In the short-term causality test includes Wald test on the $1^{\text {st }}$ difference lagged are applied while, in the long term both explanatory variables and one period lag error correction term is used.

$$
\begin{aligned}
& \Delta \ln \mathrm{TOU}_{\mathrm{t}}=\beta_{0}+\beta_{1} \ln (\mathrm{TOU})_{\mathrm{t}-1}+\beta_{2} \ln (\mathrm{CC})_{\mathrm{t}-1}+\sum_{\mathrm{i}=1}^{\mathrm{p}} \Delta \ln (\mathrm{CC})_{\mathrm{t}-\mathrm{i}}+\varepsilon_{\mathrm{t}} \\
& \Delta \ln \mathrm{TOU}_{\mathrm{t}}=\delta_{0}+\sum_{\mathrm{i}=1}^{\mathrm{n}} \mathrm{n} 1 \mathrm{i} \Delta \ln (\mathrm{TOU})_{\mathrm{t}-1}+\sum_{\mathrm{i}=1}^{\mathrm{n}} \mathrm{x} 1 \mathrm{i} \Delta \ln (\mathrm{CC})_{\mathrm{t}-1}+\epsilon_{\mathrm{t}}+\mathrm{x} 1 \epsilon_{\mathrm{t}-1} \\
& \Delta \ln \mathrm{CC}_{\mathrm{t}}=\gamma_{0}+\sum_{\mathrm{i}=1}^{\mathrm{n}} \mathrm{n} 1 \mathrm{i} \Delta \ln (\mathrm{CC})_{\mathrm{t}-\mathrm{i}}+\sum_{\mathrm{i}=1}^{\mathrm{n}} \mathrm{x} 1 \mathrm{i} \Delta \ln (\mathrm{TOU})_{\mathrm{t}-\mathrm{i}}+\epsilon_{\mathrm{t}}+\mathrm{x} 1 \epsilon_{\mathrm{t}-1}
\end{aligned}
$$

\section{Results}

In the current study, some variables are not available for all the study period. The missing data problem is related to unequal aggregation because some methods to correct for missing observations may lead to data stretching. There are some missing observations of correction models, such as multivariate regression. The study uses proc MI in the SAS program which the program can apply this type of procedures using a Bayesian approach. Then, ADF is applied and the results are represented in Table 2. The test results show that variables are stationary at the first difference.

After the unit root test, Johansen-Juselius (1990) cointegration method is used. The long term relationship is continued by the data generation model and results represent statistically significant relationship between tourism sector and climate change. The relationship is represented in Table 3 and three cointegration equations are detected in the analysis. After that, the current study determines existence of the long term relationship among the variables and maximum lag is selected for three years.
Also, critical values of the model specifications are significant at the alpha with $95 \%$. Therefore, it can be asserted that the null hypothesis can be rejected and there is a potential long-run relationship between the variables.

In the Table 3 , ARDL results are also shown and according to the results, the model does not include any serial correlation and heteroscedasticity. The F statistics result is shown in the Table 3. Since F test result is statistically significant, the null hypothesis cannot be accepted. Therefore, it can be claimed that the variables have a long-run relationship.

Due to the fact that the variables are correlated, the study further tests Granger Causality to determine the direction of the potential long run relationship. The causality can provide information about the direction (unidirectional or bidirectional) between variables. For the present study, there is a unidirectional causality running towards climate change factor to tourism, as an example, $\mathrm{CO}_{2}$ emission and methane emission which are some indicators of greenhouse gases.

Table 2. Augmented dickey fuller unit-root test results

\begin{tabular}{l|llc}
\hline \multicolumn{1}{c|}{ Variables } & At Level & \multicolumn{1}{c}{ Variables } & First Difference \\
\hline TOU & $\mathrm{P}>0.10$ & $\Delta$ TOU & $\mathrm{P}<0.05$ \\
$\mathrm{CO}_{2}$ emission & $\mathrm{P}>0.05$ & $\Delta \mathrm{CO}_{2}$ emission & $\mathrm{P}<0.05$ \\
MET emission & $\mathrm{P}>0.05$ & $\Delta \mathrm{MET}$ emission & $\mathrm{P}<0.10$ \\
EN & $\mathrm{P}>0.10$ & $\Delta \mathrm{EN}$ & $\mathrm{P}<0.05$ \\
FL & $\mathrm{P}>0.05$ & $\Delta \mathrm{FL}$ & $\mathrm{P}<0.05$ \\
\hline
\end{tabular}

The lag length is selected with AIC criteria which range from 0 to 5 . The model with and without constant and trend applied to examination of the unit root test. $\mathrm{P}>0.05$, and $\mathrm{P}<0.05$ mean the variables are not significant and significant, in sequences. 
Table 3. Johansen and juselius cointegration test results

\begin{tabular}{|c|c|c|c|}
\hline $\begin{array}{l}\text { Dependent } \\
\text { Variables }\end{array}$ & $\begin{array}{c}\text { Multivariate Cointegration } \\
\text { Results }\end{array}$ & Bounding Approach to Cointegration & $\begin{array}{l}\text { Wald } \\
\text { F-Stat }\end{array}$ \\
\hline TOU & Three cointegration equation & $\mathrm{F}_{\mathrm{TOU}}\left(\mathrm{TOU}, \mathrm{CO}_{2}, \mathrm{MET}, \mathrm{EN}, \mathrm{FL}\right)$ & $\mathrm{P}<0.05$ \\
\hline $\mathrm{CC}$ & Three cointegration equation & Fcc $\left(\mathrm{CO}_{2}, \mathrm{MET}, \mathrm{EN}, \mathrm{FL}\right)$ & $\mathrm{P}<0.05$ \\
\hline \multicolumn{4}{|c|}{ Diagnostic Test Results } \\
\hline F-Statistics & $\mathrm{P}<0.05$ & & \\
\hline $\mathrm{JB}\left(\mathrm{X}_{\text {normal }}^{2}\right)$ & $\mathrm{P}>0.05$ & & \\
\hline $\operatorname{ARCH}\left(\mathrm{X}^{2}\right.$ Arch $)$ & $\mathrm{P}<0.05$ & & \\
\hline Adjusted-R ${ }^{2}$ & Min of 0.527 and $\max$ of 0.795 & & \\
\hline CUSUM & Stable (level \%5) & & \\
\hline CUSUM $^{2}$ & Stable (level \%5) & & \\
\hline
\end{tabular}

Table 4. Granger causality test results

\begin{tabular}{|c|c|c|c|c|c|c|c|}
\hline \multicolumn{3}{|c|}{ Variables } & $\mathrm{D}$ & \multicolumn{3}{|c|}{ Variables } & $\mathrm{D}$ \\
\hline $\mathrm{CO}_{2}$ emission & $\longleftrightarrow$ & TOU (arrivals) & 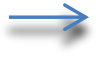 & MET emission & $\longleftrightarrow$ & TOU (arrivals) & $\overrightarrow{3}$ \\
\hline $\mathrm{CO}_{2}$ emission & $\leftarrow$ & TOU (revenue) & $\Longrightarrow$ & MET emission & $\longleftrightarrow$ & TOU (revenue) & $\Longrightarrow$ \\
\hline $\mathrm{CO}_{2}$ emission & $\longleftrightarrow$ & FL & $\leftarrow$ & MET emission & $\longleftrightarrow$ & FL & $\neq$ \\
\hline $\mathrm{CO}_{2}$ emission & $\leftarrow$ & $\mathrm{EN}$ & $\leftarrow$ & MET emission & $\leftarrow$ & EN & $\leftarrow$ \\
\hline
\end{tabular}

D: Direction

Table 5. Short and Long run Elasticity of Independent Variables (dependent variable $\Delta \operatorname{lnTOU}$ (revenue) and $\Delta \operatorname{lnTOU}($ arrivals)

\begin{tabular}{|c|c|c|c|}
\hline \multicolumn{2}{|c|}{ Dependent variable $\Delta \ln T O U$ (revenue) } & \multicolumn{2}{|c|}{ Dependent Variable $\Delta \operatorname{lnTOU}$ (arrivals) } \\
\hline Variables & Coefficient & Variables & Coefficient \\
\hline \multicolumn{4}{|c|}{ Short-Term } \\
\hline $\mathrm{CO}_{2}$ emission & Negative $<1 * *$ & $\mathrm{CO}_{2}$ emission & Negative $<1 *$ \\
\hline MET emission & Positive $<1$ & MET emission & Negative $\cong 1$ \\
\hline EN & Negative $<1 *$ & $\mathrm{EN}$ & Negative $<1 * * *$ \\
\hline FL & Positive $<1 *$ & FL & Positive $<1 *$ \\
\hline \multicolumn{4}{|c|}{ Long-Term } \\
\hline $\mathrm{CO}_{2}$ emission & Negative $<1 *$ & $\mathrm{CO}_{2}$ emission & Negative $>1 *$ \\
\hline MET emission & Positive $\cong 1$ & MET emission & Negative $<1^{*}$ \\
\hline EN & Negative $\cong 1 * * *$ & EN & Negative $\cong 1 * *$ \\
\hline FL & Positive $>1 *$ & FL & Positive $>1 * *$ \\
\hline \multicolumn{4}{|c|}{ Diagnostic Tests } \\
\hline F-Statistics & & \multicolumn{2}{|l|}{$2.52 * *-3.95 * *$} \\
\hline $\mathrm{JB}\left(\mathrm{X}_{\text {normal }}^{2}\right)$ & & \multicolumn{2}{|l|}{$\mathrm{P}>0.05$} \\
\hline $\mathrm{ARCH}\left(\mathrm{X}^{2} \mathrm{Arch}\right)$ & & \multicolumn{2}{|l|}{$P>0.05$} \\
\hline Adjusted-R ${ }^{2}$ & & \multicolumn{2}{|c|}{ Min of 0.684 and $\max$ of 0.819} \\
\hline CUSUM & & \multicolumn{2}{|c|}{ Stable (Level 5\%) } \\
\hline CUSUM $^{2}$ & & \multicolumn{2}{|c|}{ Stable (Level 5\%) } \\
\hline
\end{tabular}

$*, * *$ and $* * *$ indicates different types of significance level which are $1 \%, 5 \%$ and $10 \%$, respectively.

In the Table 5, long and short-run relationship between climatic changes indicators and tourism sector indicators are given. The results show that climate change indicators and tourism revenues are negatively related except forested areas in both short and the long term relationship. Similar directions are valid when the dependent variable is international tourist arrivals. Considering some cases, the methane emission has positive coefficient and smaller than 1 , but it is not significant at the level of 5\% statistically. In the literature, some studies have similar results such as Hilmi et al. (2013), suggesting that climate change has a wide range of impact on the natural resources. Climatic factors changes crucially affected for a shift in the tourism industry consisting tourism revenues (UNWTO, 2010).
All in all, Adjusted-R2 shows the range from $68 \%$ to $82 \%$ variation of explanatory power of the independent variables. $F$ value is statistically significant and fitness of the model is acceptable.

\section{Discussion}

Tourism industry is evaluated as an initiator sector and performs a crucial role in the development of countries' economy and labor markets. However, climate change has negatively impacted environment and thereby tourism location, and this phenomenon is especially highlighted with deterioration of $3 \mathrm{~s}$ which are sea, sand and sun. Since tourism generally relies on natural environment as 
aforementioned, the climate change may affect the tourism revenues and number of tourist arrivals. Therefore, estimation of the short term and long term relationship between climatic changes and tourism sector are crucial in the perspective of natural resource conservation and the revenue of tourism sector.

This study aims to empirically examine long-run relationship and causality between climate change and tourism sector in Turkey. For this purpose, Granger causality test is applied to evaluate the potential long run relationship between climate change and tourism sector from 1960 to 2016. The study uses World Development Indicator Data set of Turkey. For the analysis, carbondioxide emission, methane emission, energy use (oil equivalent), forest land standing for climate change and international tourist arrivals and tourism revenues representing the tourism sector are applied as fundamental variables of Turkey from 1960 to 2016.

The analysis results show that on average, climate change is negatively related with tourism industry. The results also indicate that $\mathrm{CO}_{2}$ emission and methane emission have unidirectional impact on the tourism revenues and tourist arrivals in the long term. Therefore, it can be concluded that Kuznets curve hypothesis, which is an inverted-U-shaped relationship between different pollutants and per capita income, is validated for Turkey during the study period of current study. Sarkodie and Strezov (2019) stated that the Environmental Kuznets Curve hypothesis suggests early stages of economic development are described by a large use of resources which decline the biocapacity and thus, drive to rapid growth in pollution levels.

\section{Conclusions}

All in all, the findings of the current study represent some potential policy recommendations to green environments, sustainable tourism, developing tourism industry and thus, economic development of the country. The appropriate policy can be developed for low-carbon emission (or low methane emission) and green tourism which may increment to less energy consumption (oil usage). Also, some taxes can be applied for the usage of natural resources in tourist destinations. Moreover, governments may give incentives to green and low $\mathrm{CO}_{2}$ emission energy usage technology or some alternative energy usage of companies can be supported in the long run.

\section{References}

Akhmat G, Zaman K, Shukui T, Sajjad F. 2014. Does energy consumption contribute to climate change? Evidence from major regions of the world. Renewable and Sustainable Energy Reviews, 36: 123-134.

Climate and Development Knowledge Network. 2013. Available at: https://cdkn.org/ (accessed by 10 June 2019).

Collins L, Natarajan S, Levermore G. 2010. Climate change and future energy consumption in UK housing stock. Building Services Engineering Research and Technology, 31(1): 75-90.
Collins M, Knutti R, Arblaster J, Dufresne JL, Fichefet T, Friedlingstein P, Shongwe M. 2013. Long-term climate change: projections, commitments and irreversibility. In Climate Change 2013-The Physical Science Basis: Contribution of Working Group I to the Fifth Assessment Report of the Intergovernmental Panel on Climate Change (pp. 1029-1136), Cambridge University Press.

Cunliffee S. 2002. Forecasting risks in the tourism industry using the Delphi Technique. Tourism, 50 (1): 31-41.

Dellal İ. 2008. Küresel İklim Değişikliği ve Enerji Kıskacında Tarım. İGEME'den Bakış, (35): 103-111.

Hallegatte S, Green C, Nicholls RJ, Corfee-Morlot J. 2013. Future flood losses in major coastal cities. Nature Climate Change, 3(9): 802.

Hilmi N, Allemand D, Dupont S, Safa A, Haraldsson G, Nunes PA, Fine M. 2013. Towards improved socio-economic assessments of ocean acidification's impacts. Marine Biology, 160(8): 1773-1787.

Jean-Baptiste P, Ducroux R. 2003. Energy policy and climate change. Energy Policy, 31(2): 155-166.

Katircioglu ST. 2014. International tourism, energy consumption, and environmental pollution: The case of Turkey. Renewable and Sustainable Energy Reviews, 36: 180-187.

Katircioglu ST, Feridun M, Kilinc C. 2014. Estimating tourisminduced energy consumption and $\mathrm{CO} 2$ emissions: The case of Cyprus. Renewable and Sustainable Energy Reviews, 29: 634-640.

Lam TN, Wan KK, Wong SL, Lam JC. 2010. Impact of climate change on commercial sector air conditioning energy consumption in subtropical Hong Kong. Applied Energy, 87(7): 2321-2327.

Lohmann M, Kaim E. 1999. Weather and holiday destination preferences, image attitude and experience. The Tourist Review, 2: 54-64.

Munich R. 2013. Natural catastrophes 2012 Analyses, assessments, positions 2013 issue. Topics Geo, 2013: 1-66.

Nakicenovic, N. 2010. World development report 2010: Development and climate change.

Roshan GR, Orosa JA, Nasrabadi T. 2012. Simulation of climate change impact on energy consumption in buildings, case study of Iran. Energy Policy, 49: 731-739.

Saenz-de-Miera O, Rossello J. 2014. Modeling tourism impacts on air pollution: The case study of PM10 in Mallorca. Tourism Management, 40: 273-281.

Sajjad F, Noreen U, Zaman K. 2014. Climate change and air pollution jointly creating nightmare for tourism industry. Environmental Science and Pollution Research, 21(21): 12403-12418.

Sarkodie SA, Strezov V. 2019. A review on Environmental Kuznets Curve hypothesis using bibliometric and metaanalysis. Science of the Total Environment, 649: 128-145.

Semenza JC, Ploubidis GB, George LA. 2011. Climate change and climate variability: personal motivation for adaptation and mitigation. Environmental Health, 10(1): 46.

United Nations World Tourism Organizations. Available at: https://www.unwto.org/ sustainable-developmenten/content /climate-change-tourism (accessed by 1 June 2019).

World Development Indicators, Released by World Bank, in Washington DC, USA. Available at: https://databank .worldbank.org/reports.aspx? source $=2 \&$ country=TUR (accessed by 22 June 2019). 